\title{
Hepatitis D Virus Antibody Measurement
}

National Cancer Institute

\section{Source}

National Cancer Institute. Hepatitis D Virus Antibody Measurement. NCI Thesaurus.

Code C96664.

The determination of the amount of Hepatitis D virus antibody present in a sample. 